Gandhi and Women Resurgence

Dr. Abha Chauhan Khimta

\title{
Gandhi and Women Resurgence
}

\author{
Dr. Abha Chauhan Khimta \\ Assis. Prof., Deptt. of Political Science, \\ Himachal Pradesh University \\ Summerhill, Shimla, Himachal Pradesh. \\ Email:abhackhimta@gmail.com
}

\begin{abstract}
Gandhi was neither orthodox nor conservative and not merely national in a narrow sense. His mind was always open and eclectic. He would absorb ideas from anywhere and adopt them if they were in tune with the higher ideals he cherished. For Gandhi any thought or action which would go counter to the spiritual growth of the people and which were detrimental to the freedom, dignity and self-respect of the soul of man and which would act as an obstacle to self-realisation was unacceptable. So, he made no distinction between man and woman so far as the spiritual goal and the way to it were concerned. He believed that man and woman are complementary to each other. The present paper is an attempt to explore women resurgence and Gandhian perspective on it.
\end{abstract}

Key Words: Orthodox, Conservative, Self-realisation, Resurgence.
Reference to this paper should be made as follows:

Received: 24.01.2020

Approved: 05.03.2020

Dr. Abha Chauhan

Khimta,

Gandhi and Women Resurgence

Article No. 02

RJPSS March 2020,

Vol. XLV No. 1, pp. 008-015

Online available at: https://anubooks.com/ ?page id $=6389$

https://doi.org/10.31995/ rjpss.2020.v45i01.002 
RJPSS March 2020 Vol. XLV No.1, ISSN: (P)0258-1701 (e)2454-3403 Impact Factor: 7.712

\section{Introduction}

Gandhi always wrote with a purpose and described himself as a man of action. In his public and private life, he translated into action, all that he spoke or wrote. What he wrote and spoke was very Indian and regarded his ideas as old as hills. He was a great revolutionary and left indelible impact on the social, economic and political forces of the day. Gandhi intertwined the freedom struggle and the movement of national reconstruction. Reconstruction was integral in his meaning of freedom and freedom would be incomplete. He set a unique example amongst Indian leaders by including women among the masses in a most natural way. Women participation in mass movements led by him made a big breakthrough in Indian women's lives forever. His deep faith in women's Shakti came from his experience of his mother and his wife. He observed and studied women in his home as human being and perceived them as equal partners in the home and society. Gandhi's strategy to fight for freedom could not ignore women. He made no distinction between man and woman so far as the spiritual goal and the way to it were concerned. However he made it clear that equality did not mean uniformity or mere mechanical similarity. Equality for him meant equal opportunities in life. Very few social reformers and workers in the women's cause have thought so fundamentally and deeply as Gandhi.

\section{Feminist Resurgence in the World}

More than last hundred years may rightly be called the age of woman's awakening in this world. History provides various references regarding independence of women in certain communities. Such independence was truer of the primitive communities or of communities which had been left out of the main stream of European civilization. For even on unassailable strongholds of democracy like Athens, women were merely possessions and obtained education under great difficulties. If Plato wrote that, "as far as the state is concerned there is no difference between the natures of men and women"It was because of the unequal laws and customs then prevailing in Greece. His plea that women ought to be admitted to all the duties and rights of man and his warning regarding the loss to the state as a result of their restricted spheres of activity still remain unheard. The most remarkable thing about the story of women's progress towards freedom and equality is the strange uniformity of its pattern. Whether in Africa, America, Asia or Europe, the prejudices that hamper the path of progress, the obstacles that woman has to encounter and surmount seem almost identical. This makes the struggle not a national one but a human one. It can be argued that the peculiar disability attached to woman all over the world is based on religion. Political disability is also biologically defined and becomes the basis for 
Gandhi and Women Resurgence

Dr. Abha Chauhan Khimta

economic and social disabilities. The proper slogans 'liberty, Equality and fraternity'applied only to man, because the religious prejudice against woman triumphed even when reason was presumed to have replaced religion. ${ }^{2}$ Even in the United States the question of franchise for women was considered at the constitutional convention of 1787 and was referred to the individual colonies. Jefferson stood for the exclusion of women from political activity in democracy. The object of such exclusion was to prevent depravation of morals and ambiguity of issues which would result if women were to mingle with men in public meetings.

The advance of capitalism in the West had induced inequality on the one hand and broadened the search for equality on the other. Feminism in the West emerged in this context. Women's movements were the early social movements to press for demands to ensure women's equality. Within the liberal tradition in women's movements in the West, Moderate feminists believed that there should be equal opportunity for all. While radical feminists believed that exploitation of women by men has its origin in reproductive biology. They believed that women and children should be given the freedom to choose the lifestyle that suits them best.Feminists within the socialist tradition were influenced by Marx and Engels. They strongly believed that women should demand equal pay and equal opportunity in education and employment. ${ }^{3}$ Women liberation movement had different origins in the West organisationally. In England they started as trade union movements and in Italy as Marxist student groups. In America, the movement started as the Black Power struggle which induced the women's consciousness. In the beginning, the women liberation movements in the West were primarily concerned with liberal legislative reforms. Voting rights for all including women was one of their main issues. ${ }^{4}$ The main objective of women liberation movement was to challenge male political and intellectual hegemony. They were often characterised as anti-male and anti-family. Women carried, placards proclaiming 'starve a rat- do not cook dinner' Marriage was regarded a form of slavery and they used unconventional methods of protests, strikes and demonstrations. ${ }^{5}$

International action to raise the status of women began in a small way with the League of Nations. In the $15^{\text {th }}$ Assembly of the League, a resolution expressing appreciation of the work done by women in support of the League of Nations could be noted. It was declared that the equal status of men and women was a prerequisite of the effective collaboration of women in the work of the League. It was also decided that there collaboration could be effectively exercised through the competent official organs of the League and of the Governments concerned. The united nation 
charter went further to give effect to the principles of equality and freedom. It had also adopted a convention on Political Rights of Women. ${ }^{6}$

\section{Gandhi and Women in India}

Nineteenth and Twentieth century review clearly illustrate that many of the earlier agitators for women emancipation were men. Social reformers like Raja Rammohan Roy, Tagore, Gandhi, Nehru and Syed Ahmed Khan had raised issues related to women. Indian freedom struggle had precipitated diverse strains of thought and a wide spectrum of ideas. It aimed at a thorough transformation of Indian society and women issues were also brought to the centre-stage activities. Mahatma Gandhi enhanced the participation of women in the national movement through noncooperation and civil disobedience. He had sought the support of women for almost all of his political movements- non cooperation, civil disobedience and quit India movement.Educated women played a unique role in the implementation of the Gandhian Progress. It is argued that 1970s had witnessed a reawakening of women's consciousness in India. ${ }^{7}$ Gandhi was champion of women's emancipation during his time. On his return from South Africa in 1915, he realised that people were unaware about swaraj. He declared that women should be made aware of present condition. Gandhi believed that self realisation should be ultimate objective of both men and women. He believed that a man should remain man and yet should become woman. Similarly a woman should remain woman and yet become man. This meant that man should cultivate the gentleness and the discrimination of woman and woman should cast off her timidity and become brave and courageous. ${ }^{8} \mathrm{He}$ suggested that woman can become fearless and they should control their passions. He said, "Only the self can raise the self; the self is the help of the self. Only women can raise women. This requires tapascharya and hard work. It is true that women are more capable of it than men; but the tapascharya must be intelligent. Today women merely toil on in a helpless condition like drudges." Gandhi considered women as the incarnation of ahimsa. This meant the infinite capacity for suffering. He said, "Who but woman, the mother of man, shows this capacity in the largest measure? She shows it as she

carries the infant and feeds it during nine months and derives joy in the suffering involved. What can beat the suffering caused by the pangs of labour? But she forgets them in the joy of creation. Who again suffers daily so that her babe may wax from day to day? Let her transfer that love to the whole of humanity, let her forget she ever was or can be the object of man's lust. And she will occupy her proud position by the side of man as his mother, maker and silent leader. It is given to her to teach the art of peace to the warring world thirsting for that nectar. She can become the 
Gandhi and Women Resurgence

Dr. Abha Chauhan Khimta

leader in Satyagraha which does not require the learning that books give but does require the stout heart that comes from suffering and faith." 10

Gandhi firmly believed that fundamentally men and women are one and their problems must be one in essence. He blamedmanfor dominating women from ages past and so they had developed an inferiority complex. Gradually she started believing in the truth of man's interested teaching that she is inferior to him.According to Gandhi,however the seers among men had recognised her of equal status. He believed that while both are fundamentally one, it is also equally true that in the form there is a vital difference between the two. Hence for Gandhi the vocations of the two must also be different. He said, "The duty of motherhood, which the vast majority of women will always undertake, requires qualities which man need not possess. She is passive, he is active. She is essentially mistress of the house. He is the bread winner. She is the keeper and distributor of the bread. She is the caretaker in every sense of the term. The art of bringing up the infants of the race is her special and sole prerogative. Without her care the race must become extinct. In my opinion it is degrading both for man and woman that woman should be called upon or induced to forsakethe hearth and shoulder the rifle for the protection of that hearth. It is a reversion to barbarity and the beginning of the end. In trying to ride the horse that man rides, she brings herself and him down." 11 Gandhi firmly believed that it is tyrannical to burden women with work which is ordinarily done by men. He advocated for the strong and independent role of women in politics. He pointed out that women in politics are mainly tools in the hands of male members of their family. He said, "Today few women take part in politics and most of these do not do independent thinking. They are content to carry out their parent's or their husband's behests. Realising their dependence, they cry out for women's rights. Instead of doing this, however, women workers should enrol women as voters, impart or have imparted to them practical education, teach them to think independently, release them from the chains of caste that bind them, so as to bring about a change in them which will compel men to realise woman's strength and capacity for sacrifice and give her places of honour." "Woman in Gandhi's view is entitled to a supreme place in her own sphere of activityas man is in his. Though he encouraged women to take part in public life to an extent that was never known before, he wished them in the new order of his imagination to be part time workers, their primary function, in his opinion, being to look after the home. Rabindranath Tagore also expressed his views in the same tune regarding women. He said, "Man has already achieved the means of self expression in public activity without giving up his individual concerns. When, likewise, 
any society shall be able to offer a larger field for the creative work of women's special faculty, without detracting from her creative work in the home, then in such society will the true union of man and woman become possible."13

Gandhi made no distinction between man and woman so far as the spiritual goal was concerned. At the same time, he was not blind to the biological difference which nature had made and the difference in the spheres and functions of the two sexes. While he was uncompromising in upholding the equality of the sexes and their respective rights, he was equally clear that equality did not mean either uniformity or mere mechanical similarity. Equality for him meant equal opportunities in life. He held that man and woman though equal, were complementary to each other and neither was complete without the other. Gandhi emphasised that before a woman is one's wife, she is his mother. This means that the first contact of man with woman is in the capacity and relationship of mother and child. This is the purest, the highest and the noblest of relationships between humans and this is the very basis and foundations of society. He pointed that most of the great men of the world owe their personality and the formation of their basic character to their noble mothers. ${ }^{14}$ While answering the question of those female workers who work in fields, factories etc. He said, "If millions of women are forced to forsake their hearth and become bread winners, it is wrong, but not as wrong as shouldering the rife. There is nothing inherently barbarous in labour. I see no barbarity in women voluntarily working on their fields whilst they are looking after their homes. In the new order of my imagination, all will work according to their capacity for an adequate return for their labour. Women in new order will be part time workers, their primary function being to look after the home. Since I do not regard the rifle as a permanent feature in the new order, its use will be progressively restricted even so far as men are concerned. It will be tolerated as a necessary evil while it lasts. But I would not deliberately contaminate women with the evil." ${ }^{15}$ According to Gandhi, women had turned her weakness into strength. His whole concepts rested on this philosophical and moral notion. The fight of weak against the strong is possible only when the weak perceive their weakness as strength and as a strategy to overpower their enemy. Gandhi linked the weakness of women and its transformation into strength as part of the same strategy and as embodied in the conceptions of Satyagraha and Ahimsa.According to him, the biological characteristics of having reproductive capacities and of being mother, give woman, "The power, denied to men, of creating new ideals and translating them into action. By comparison, man is thoughtless, impatient and given to the pursuit of novelty. Women, it is observed, are serious minded, patient and inclined generally to cling to 
Gandhi and Women Resurgence

Dr. Abha Chauhan Khimta

old ways. When, therefore, she has a new idea, it seems to have its birth in the tender depths of her heart. An idea and for that reason it is capable of being rapidly propagated." ${ }^{16}$ In Gandhi's perception, a woman develops qualities and attributes such as courage, patience purity and suffering which are exclusive to her too superior to male. He stated, "Men and women are of equal rank, but they are not identical. They are a peerless pair, being supplementary to one another, each helps the other so that without the one, the existence of the other cannot be conceived...Man is superior in the outward activities of a married pair and, therefore, it is in the fitness of things that he should have a greater knowledge thereof. On the other hand, home life is entirely in the sphere of women, and, therefore, in domestic affairs, in the upbringing and education of children, women ought to have more knowledge." 17

\section{Conclusion}

It can be stated Mahatma Gandhi had been given the love of many women for his womanliness. For all those qualities that are associated with women like, great faith, great fortitude, great devotion, great patience, great tenderness and great sympathy. They could sense in him a fellow traveller, one who had passed ahead along the road they too were travelling and could give him affection deep and pure. Women of all kinds had turned to him in perplexity and trouble. All problems of their lives could be discussed with frankness and straight forwardness. They were sure that some light would be thrown upon their difficulties and the path made to look not too arduous to travel.Thus Gandhi's ideas on women are remarkably similar to those voiced by the women's liberation movement all over the world. His greatest contribution was to raise women's status without belittling their roles as mother and wives. Gandhi saw women not as objects of reform and humanitarianism, but as self- conscious arbiters of their destiny.

\section{References}

1 Lakshmi Menon, "Women in India and Abroad," in Women of India, ed. By Tara Ali Baig(NewDelhi: Ministry of Information and Broadcasting of India, 1958), p.54.

$2 \quad$ Ibid. P.55.

3 Clymes Augustine\&A.K.Sharma, "Feminist Resurgence in India: Towards a Gandhian Frame Work," Gandhi Marg, Vol.14, No.3. October-December 1992, p.490.

4 Ann Oakley, "Women's Studies in British Sociology: To End at Our Beginning," The British Journal of sociology (London), Vol.40, No.3, 1989, p.443. 
RJPSS March 2020 Vol. XLV No.1, ISSN: (P)0258-1701 (e)2454-3403 Impact Factor: 7.712

5 Ethel Kelien, Gender Politics:from Consciousness to Mass Politics(Cambridge: Harvard University Press, 1984), p.126.

6 lakshmiMenon, "Women in India and Abroad" in Women in India, p.66.

7 Clymes Augustine \&A.K.Sharma, "Feminist Resurgence in India: Towards a Gandhian Framework," Gandhi Marg, pp. 494-495.

8 RaghvanIyer, The Moral and Political Writings of Mahatma Gandhi (Oxford: Clarendon Press, 1973), Vol.3, pp. 1-2.

9 Ibid. p.394.

10 Shriman Narayan ed., The Voice of Truth (Ahmedabad: Navajivan Publishing House, 1969), p.482.

11 Ibid., p.481.

12 Ibid., p.488.

13 ChandrashankerShukla, Gandhi's View of life: An Essay in Understanding(Bombay:BhartiyaVidyaBhavan, 1951), p.203.

14 R.R.Diwakar, Gandhi: The Spiritual Seeker (Bombay: BhartiyaVidyaBhavan, 1964), p.85.

15 Mahatma Gandhi, Women and Social Justice(Ahmedabad:Navajivan Publishing House, 1942), p. 28.

16 Sujata Patel, "Construction and Reconstruction of Women in Gandhi," Economic and Political Weekly, Vol.XXIII, No. 8, Feb.20, 1988, p.381.

17 Ibid. 